\title{
The efficiency of concentration methods used to detect enteric viruses in anaerobically digested sludge
}

\author{
Tatiana Prado $/^{+}$, Wilma de Carvalho Pereira Bonet Guilayn², \\ Ana Maria Coimbra Gaspar ${ }^{3}$, Marize Pereira Miagostovich ${ }^{1}$

\begin{abstract}
'Laboratório de Virologia Comparada e Ambiental ' 2 aboratório de Desenvolvimento Tecnológico em Virologia, Instituto Oswaldo Cruz-Fiocruz, Rio de Janeiro, RJ, Brasil ${ }^{2}$ Departamento de Saneamento e Saúde Ambiental, Escola Nacional de Saúde Pública-Fiocruz, Rio de Janeiro, RJ, Brasil
\end{abstract}

\begin{abstract}
The presence of enteric viruses in biosolids can be underestimated due to the inefficient methods (mainly molecular methods) used to recover the viruses from these matrices. Therefore, the goal of this study was to evaluate the different methods used to recover adenoviruses (AdV), rotavirus species A (RVA), norovirus genogroup II (NoV GII) and the hepatitis $A$ virus (HAV) from biosolid samples at a large urban wastewater treatment plant in Brazil after they had been treated by mesophilic anaerobic digestion. Quantitative polymerase chain reaction (PCR) was used for spiking experiments to compare the detection limits of feasible methods, such as beef extract elution and ultracentrifugation. Tests were performed to detect the inhibition levels and the bacteriophage PP7 was used as an internal control. The results showed that the inhibitors affected the efficiency of the PCR reaction and that beef extract elution is a suitable method for detecting enteric viruses, mainly AdV from biosolid samples. All of the viral groups were detected in the biosolid samples: AdV (90\%), RVA, NoV GII (45\%) and HAV (18\%), indicating the viruses' resistance to the anaerobic treatment process. This is the first study in Brazil to detect the presence of RVA, AdV, NoV GII and HAV in anaerobically digested sludge, highlighting the importance of adequate waste management.
\end{abstract}

Key words: enteric viruses - anaerobically digested sludge - concentration methods - virus recovery yields

Wastewater treatment plants (WWTPs) generate large amounts of residual sludge as part of the sewage treatment process. This sludge contains a series of concentrated contaminants, mainly heavy metals and pathogenic microorganisms, such as bacteria, viruses, protozoa and helminths (Monpoeho et al. 2004, Guzmán et al. 2007, Viau \& Peccia 2009, Wong et al. 2010).

Enteric viruses, which cause several diseases, including hepatitis and gastroenteritis, can be detected at high concentrations in sludge and represent a potential health risk due to disposal and reuse practices (Sidhu \& Toze 2009). In Brazil, approximately $40 \%$ of the sewage sludge generated in WWTPs is disposed of in landfills, $15 \%$ is discharged in rivers, $8 \%$ is disposed of in wastelands, $2 \%$ is incinerated, $0.1 \%$ in discharged in the ocean and $15 \%$ is reused (IBGE 2008).

Sewage sludge may have beneficial uses because it contains nutrients and organic matter and may be used as soil fertiliser or for soil improvement (Godfree \& Farrell 2005). However, under certain conditions, these practices could lead to the contamination of surface water, groundwater, soil and the food chain.

Several stabilisation treatments are used to reduce the organic matter and pathogens in sludge, otherwise known as biosolids. Mesophilic anaerobic digestion (MAD),

Financial support: CNPq/PAPESV (403530/2008-3), IOC-FIOCRUZ + Corresponding author: tprado@ioc.fiocruz.br

Received 1 June 2012

Accepted 8 August 2012 aerobic digestion, composting, air drying and lime stabilisation are among the most commonly used treatments. Virus resistance to different stabilisation treatments is variable (Godfree \& Farrell 2005), e.g., enteric viruses have been found in treated sewage sludge (Monpoeho et al. 2004, Viau \& Peccia 2009, Wong et al. 2010).

Most concentration methods used to detect viruses in sewage sludge involve an elution and concentration step. Beef extract, an eluent recognised by the US EPA (2003), has been reported to concentrate inhibitors in the final eluent, thereby affecting polymerase chain reaction (PCR) efficiency (Sano et al. 2003, Rock et al. 2010).

Some concerns that need to be addressed include the standardisation of simplified concentration methods and establishment of detection limits to ensure a reliable health risk analysis (Girones et al. 2010). In addition, information on detecting the presence and concentration of rotaviruses and norovirus (NoV) in biosolids (Sidhu \& Toze 2009) is limited; therefore, this study aimed to evaluate the different concentration methods for recovering adenoviruses (AdV), rotaviruses A (RVA), NoV genogroup II (NoV GII) and hepatitis A viruses (HAV) from digested mesophilic sludge samples by using a realtime PCR assay for virus detection. To avoid false negative results, bacteriophage PP7 was used as an internal control (IC) for the multiplex quantitative PCR (qPCR) assays (Rajal et al. 2007, Fumian et al. 2010). Digested mesophilic sludge samples obtained from a conventional activated sludge process were evaluated for the presence and concentration of AdV, RVA, NoV GII and HAV. Different virus concentration methods were used and detection was conducted by qPCR assay. This paper discusses the efficacy of these concentration methods. 


\section{MATERIALS AND METHODS}

Biosolid samples - Digested mesophilic sludge samples (biosolids) were obtained from a large urban WWTP located in Rio de Janeiro (RJ), Brazil. The WWTP receives urban sewage with a mean inflow rate of $1.600 \mathrm{~L} \mathrm{~s}^{-1}$. The WWTP utilises an aerobic process (conventional activated sludge), MAD and dewatering in its treatment process. From February-July 2011, 11 biosolid samples were collected after MAD. Samples were collected monthly (with 15 days intervals, approximately), except in March, when four biosolid samples were provided by the Wastewater Sanitation Company (CEDAE). These biosolids are the final product of the treatment process. Samples were collected in sterile plastic bags, kept at $4^{\circ} \mathrm{C}$ and transported to the laboratory for immediate analysis.

Viruses and the IC - RVA G1P[8] (GenBank accession GU831596) and NoV GII/4 strain (GenBank accession DQ997040), both of which were isolated from a positive faecal suspension (10\%) and identified during acute gastroenteritis outbreaks in Brazil, were used in the spiked experiments. The AdV serotype 5, which was propagated in cell culture (Hep-2) and the HAV strain (HAF-203), which was propagated in Rhesus kidney cell cultures (FRhK-4), were used in all of the experiments (Villar et al. 2006). A PP7 bacteriophage (ATCC 15692-B2) was kindly provided by Dr Verónica Rajal (Salta University, Argentina) and included as an IC. Its replication was performed by culture in Pseudomonas aeruginosa (ATCC 15692) using a previously described protocol (Rajal et al. 2007).

Virus stock solutions were quantified according to real-time PCR protocols (Table I) to determine the viral concentrations used to spike the biosolid samples.

Virus concentration methods - Viruses were concentrated using two different techniques. Method 1, described by Pina et al. (1998), consists of an ultracentrifugation-based method, with minor modifications. Briefly, $5 \mathrm{~g}$ [dry matter (d.m.)] of biosolid were suspended in 15 $\mathrm{mL}$ of $0.25 \mathrm{~N}$ glycine buffer ( $\mathrm{pH} 9.5$ ) and incubated on ice for $30 \mathrm{~min}$. The solution was neutralised by adding $10 \mathrm{~mL}$ of $2 \mathrm{x}$ phosphate-buffered saline (PBS) (pH 7.2). The mixture was centrifuged $\left(12,000 \mathrm{~g}\right.$ for $\left.15 \mathrm{~min}, 4^{\circ} \mathrm{C}\right)$ and the supernatant was ultracentrifuged (Beckman ultracentrifuge, equipped with a type 35 rotor) at 100,000 $g$ for $1 \mathrm{~h}$ at $4^{\circ} \mathrm{C}$. The pellet was resuspended in $1.0 \mathrm{~mL}$ of 1 x PBS, pH 7.2.

Method 2, described by Guzmán et al. (2007), consists of a simplified method similar to that used by the US EPA (2003). Briefly, 10\% beef extract solution (LP029B, Oxoid Ltd Basingstoke, Hants, England), pH 7.2 at 1:10 $(\mathrm{v} / \mathrm{v})$ or $(\mathrm{w} / \mathrm{v})$ was added to $5 \mathrm{~g}$ (d.m.) of sewage sludge. The sample was magnetically stirred $(500 \mathrm{rpm})$ for 20 min at room temperature. Afterwards, the sample was centrifuged at $4000 \mathrm{~g}$ for $30 \mathrm{~min}$ at $4^{\circ} \mathrm{C}$. The supernatant was recovered and filtered through low protein binding membrane filters (Millipore, $0.22 \mu \mathrm{m}$ pore size) to decontaminate it.

All of the concentrated samples were stored at $-70^{\circ} \mathrm{C}$ until molecular biology analysis was performed.

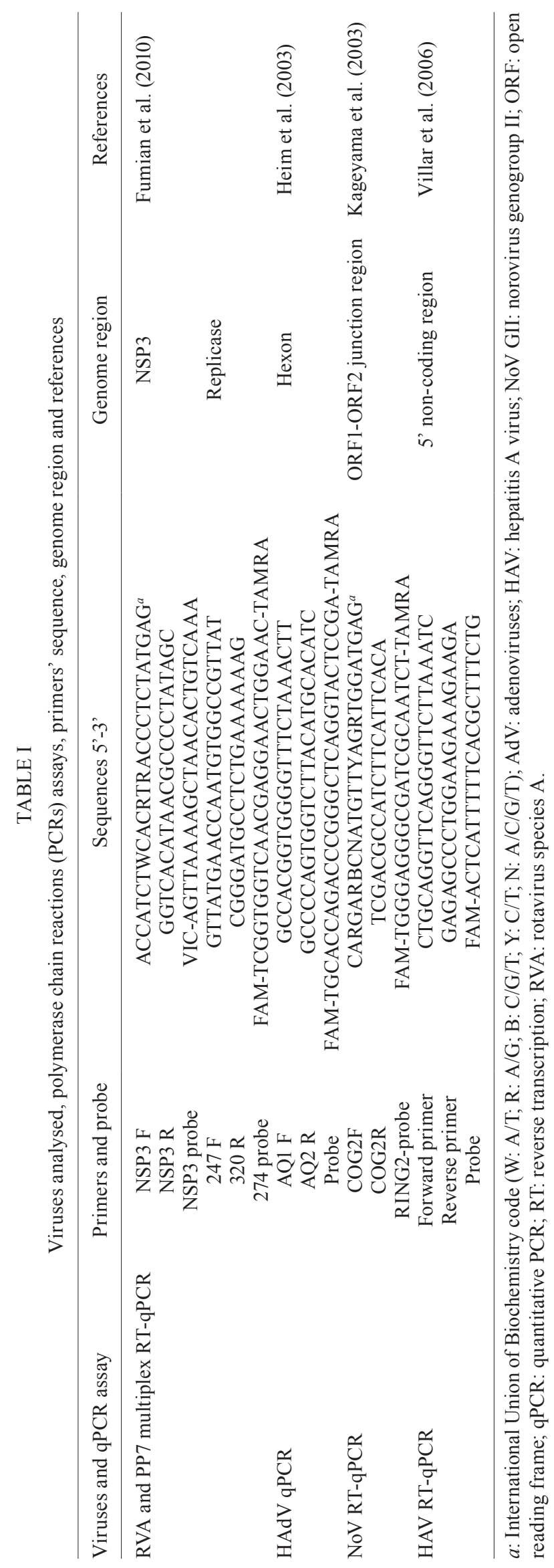


Spike experiments and inhibition tests - The biosolid samples were autoclaved at $121^{\circ} \mathrm{C}$ for $30 \mathrm{~min}$ for decontamination. Viruses were spiked in $5 \mathrm{~g}$ [d.m. - determined according to US EPA (2003)] of biosolid sample and the virus titres (final concentrations) seeded into the samples were determined by a qPCR assay. The viral titres spiked in each method were as follows $\left(\mathrm{GC} \mathrm{mL}^{-1}\right)$ : Method 1: $1.1 \times 10^{9}(\mathrm{AdV}), 3.2 \times 10^{6}$ (RVA), $1.4 \times 10^{4}$ (NoV), $2 \times 10^{5}$ (HAV) and 4.2 x 10 (PP7); Method 2: 2.7 x $10^{7}(\mathrm{AdV}), 3.8 \times 10^{6}[ \pm$ standard deviation (SD) $2.8 \times$ $10^{5}$ ] (RVA), $3.4 \times 10^{4}\left( \pm \mathrm{SD} 2.3 \times 10^{4}\right)(\mathrm{NoV}), 9 \times 10^{5}( \pm$ $\left.\mathrm{SD} 1 \times 10^{6}\right)(\mathrm{HAV})$ and $4.2 \times 10^{7}(\mathrm{PP} 7)$.

Viruses were adsorbed onto sludge flocs by adjusting the $\mathrm{pH}$ to $3.5 \pm 0.1$ with $\mathrm{HCl}(1 \mathrm{~N})$, as described by Sano et al. (2003), and magnetically stirring the samples for $30 \mathrm{~min}$. The biosolid samples were then centrifuged $\left(10,000 \mathrm{~g}, 15 \mathrm{~min}, 4^{\circ} \mathrm{C}\right)$ and the supernatant $(1 \mathrm{~mL})$ and pellet generated in each experiment were analysed with a qPCR assay to determine the virus recovery yield. Procedures were performed in triplicate and repeated on different dates. In all of the experiments, negative controls were also included (unseeded decontaminated biosolid samples). Extracted nucleic acids were diluted in RNA/ DNAse free water using tenfold serial dilutions (1:10 and 1:100) to verify inhibitors of the PCR reactions. PP7, which was used as an IC for the biosolid samples, was spiked with high concentrations of viral particles (ranging from $10^{7}-10^{9}$ ). The initial viral titres used in the spiked experiments were diluted to test the limits of virus detection when using the concentration methods and qPCR assays.

Viral genomic extraction and the reverse transcription (RT) reaction - Nucleic acids were extracted from $140 \mu \mathrm{L}$ of the eluate to obtain a final volume of $60 \mu \mathrm{L}$ using the QIAamp Viral RNA kit (Qiagen, Inc, Valencia, $\mathrm{CA}$ ) according to the manufacturer's instructions.

cDNA synthesis was conducted by RT using a random primer $\left(\mathrm{PdN}_{6}, 50 A_{260}\right.$ units, Amersham Biosciences, Chalfont St Giles, Buckinghamshire, UK) for RV, NoV GII, HAV and PP7. Two microlitres of dimethyl sulphoxide (Sigma, St. Louis, MO) and $10 \mu \mathrm{L}$ of RNA were mixed briefly, heated at $97^{\circ} \mathrm{C}$ for $7 \mathrm{~min}$ and chilled for 4 min. The components of the mixture and their final concentrations for the $50-\mu \mathrm{L}$ RT reaction were as follows: $2.5 \mathrm{mM}$ of each deoxynucleoside triphosphate (GIBCO BRL, Life Technologies, Inc, Grand Island, NY), $1.5 \mathrm{mM}$ $\mathrm{MgCl}_{2}, 200 \mathrm{U}$ of Superscript III reverse transcriptase (Invitrogen) and $1 \mu \mathrm{L}$ of $\mathrm{PdN}_{6}$. The $\mathrm{RT}$ reaction mixture was incubated in a thermal cycler (PTC-100 Programmable Thermal Controller, MJ Research, Inc, Watertown, MA) at $25^{\circ} \mathrm{C}$ for $5 \mathrm{~min}, 50^{\circ} \mathrm{C}$ for $60 \mathrm{~min}$ and $70^{\circ} \mathrm{C}$ for $20 \mathrm{~min}$.

$q P C R$ - The sequence of primers and probes, region of amplification on the genome and references to qPCR protocols for virus quantification can be found in Table I.

To avoid false-positive results, quality control measures such as the use of separate rooms and the inclusion of negative controls in each set of amplifications were adopted. Inhibition tests were performed by diluting nucleic acids (10-fold serial dilutions: 1:10 and 1:100) in all of the analysed samples.
A standard curve $\left(10^{7}-10^{1}\right.$ copies per reaction) was generated for all of the viruses using 10 -fold serial dilutions of pCR2.1 vectors (Invitrogen, USA) containing the target region. The qPCR reaction was performed in a final volume of $25 \mu \mathrm{L}$ by using $12.5 \mu \mathrm{L}$ of the Universal PCR Master Mix (Applied Biosystems, CA, USA) and $5 \mu \mathrm{L}$ of the DNA/cDNA under the following incubation conditions: $50^{\circ} \mathrm{C}$ for $2 \mathrm{~min}$ to activate $\mathrm{UNG}, 95^{\circ} \mathrm{C}$ for $10 \mathrm{~min}$ for initial denaturation, $40-45$ cycles at $95^{\circ} \mathrm{C}$ for $15 \mathrm{~s}$ and then $50-60^{\circ} \mathrm{C}$ for $1 \mathrm{~min}$, depending on virus type. Amplification data were collected and analysed using Applied Biosystems 7500 Software $^{\circledR}$ version 2.0 (Applied Biosystems, Foster City, CA). All of the reactions were performed in duplicate. A positive result was considered when the sample signals crossed the threshold line, presenting a characteristic sigmoid curve. The number of viral particles was determined by adjusting the values according to the volumes used for each step of the procedure (extraction, cDNA synthesis and qPCR reaction). The amount of genome copies (GC) detected using each methodology was reported in $\mathrm{g}$ (d.m.) of concentrated sample.

The total number of viral particles spiked in the samples (per $\mathrm{mL}$ ) vs. the total number of viral particles recovered (per g dry matter) was considered to estimate the virus recovery efficiency (\%).

\section{RESULTS}

Virus recovery efficiency - Three different virus concentration methods were tested to evaluate the recovery efficiencies for each type of virus. PP7 bacteriophage was used as an IC in all of the experiments. The mean values $\left(\mathrm{GC} \mathrm{mL} \mathrm{mL}^{-1}\right)$ of the viruses detected in the supernatant of the spiked experiments (i.e., viruses not adsorbed onto sludge flocs) are shown in Table II. All of the viruses analysed were adsorbed onto sludge flocs in percentages higher than 99\% (Table II). Negative results were obtained for all of the viruses analysed in the negative control samples.

Higher mean viral loads (VLs) $\left(\mathrm{GC} \mathrm{g}^{-1}\right.$ d.m.) from each method performed, including the inhibition tests, are shown in Fig. 1. In general, higher mean VLs were recovered when the nucleic acids were diluted at least once (1:10), except for the RVA in Method 1 (Fig. 1).

PP7 was recovered from all of the analysed samples and the mean VLs detected by Methods 1 and 2 were as follows: $5.2 \times 10^{6} \mathrm{GC} \mathrm{g}^{-1} \pm \mathrm{SD} 1.1 \times 10^{6}$ and $2.8 \times 10^{6}$ $\mathrm{GC} \mathrm{g}^{-1} \pm \mathrm{SD} 2.3 \times 10^{6}$, respectively. When the nucleic acids were diluted 1:100 in Method 2, a higher mean recovery rate was obtained for PP7: $1.3 \times 10^{7} \pm \mathrm{SD} 1.1$ x $10^{7} \mathrm{GC} \mathrm{g}^{-1}$ (Fig. 2).

The mean maximum value $\left(\mathrm{GC} \mathrm{g}^{-1}\right)$ obtained from each procedure performed in triplicate (including the dilution of nucleic acids to $1: 10$ or 1:100) was considered in the analysis of the virus mean recovery rates (\%) for each virus type (Fig. 2). Ultracentrifugation was considered more suitable for recovering both RVA and HAV (Fig. 2). NoV was recovered at similar rates using Methods 1 and 2 (Fig. 2). However, AdV was better recovered by Method 2 (Fig. 2), which was based on viral elution using beef extract. 
TABLE II

Percentage of viruses adsorbed on sludge flocs

\begin{tabular}{lccc}
\hline & $\begin{array}{c}\text { Viruses spiked onto } \\
\text { sludge samples } \\
\left(\mathrm{GC} \mathrm{mL} \mathrm{mL}^{-1}\right) \\
\mathrm{mean}^{a} / \mathrm{SD}\end{array}$ & $\begin{array}{c}\text { Viruses in supernatant } \\
\left.(\mathrm{GC} \mathrm{mL})^{-1}\right) \\
\mathrm{mean}^{a} / \mathrm{SD}\end{array}$ & $\begin{array}{c}\text { Viruses adsorbed on sludge flocs } \\
(\%)\end{array}$ \\
\hline AdV & $4 \times 10^{8} / 5.9 \times 10^{8}$ & $6.7 \times 10^{3} / 5.4 \times 10^{3}$ & 99.99 \\
RVA & $3.5 \times 10^{6} / 2.8 \times 10^{5}$ & $8.5 \times 10^{2} / 8.5 \times 10^{2}$ & 99.97 \\
NoV & $3.6 \times 10^{4} / 1.9 \times 10^{4}$ & $2.5 \times 10 / 1.5 \times 10$ & 99.93 \\
HAV & $2.7 \times 10^{5} / 6.3 \times 10^{4}$ & $2.6 \times 10^{2} / 4.5 \times 10^{2}$ & 99.90 \\
PP7 & $4.2 \times 10^{7} / 0$ & $4.2 \times 10^{5} / 4.0 \times 10^{5}$ & 99.0 \\
\hline
\end{tabular}

$a$ : methods were performed in triplicate; AdV: adenoviruses; GC: genome copies; HAV: hepatitis A virus; NoV GII: norovirus genogroup II; RVA: rotavirus species; SD: standard deviation.

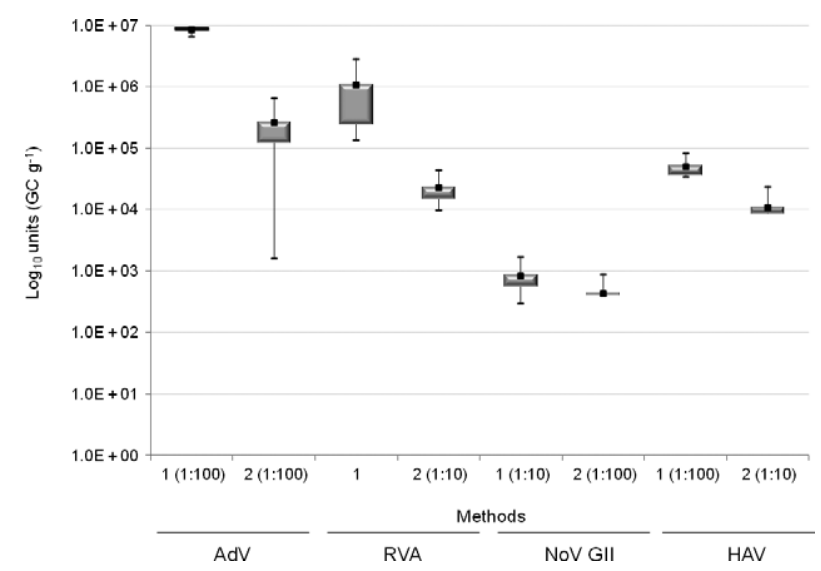

Fig. 1: mean numbers in $\log _{10}$ units of viruses recovered [genome copies (GC) $\mathrm{g}^{-1}$ ] from biosolid samples. Methods were performed in triplicate. Ten-fold serial dilution of nucleic acids are shown in parenthesis (1:10 and 1:100) on the $\mathrm{x}$ axis. Viral titres spiked are described in Materials and Methods. AdV: adenoviruses; bars: minimum and maximum value; HAV: hepatitis A virus; Method 1: ultracentrifugation; Method 2: beef extract; NoV GII: norovirus genogroup II; RVA: rotavirus species A; square in black: mean value.

The detection limits of the qPCR assays were tested for Methods 1 and 2. HAV showed the worst results in both methods, with detection limits higher than $10^{3} \mathrm{GC}$ $\mathrm{mL}^{-1}$. For $\mathrm{NoV}$, the detection limits were $1.4 \times 10^{2} \mathrm{GC}$ $\mathrm{mL}^{-1}$ and $4.8 \times 10^{2} \mathrm{GC} \mathrm{mL}^{-1}$ for Methods 1 and 2, respectively. The detection limits for $\mathrm{AdV}$ were $1.1 \times 10^{3}$ GC $\mathrm{mL}^{-1}$ and $1.5 \times 10^{2} \mathrm{GC} \mathrm{mL}^{-1}$ for Methods 1 and 2, respectively. Finally, for RVA the detection limit was $3 \mathrm{x}$ $10^{1} \mathrm{GC} \mathrm{mL}^{-1}$ for both methods.

Natural occurrence of enteric viruses - Table III shows the VL for AdV, RVA, NoV and HAV from 11 biosolid samples collected from an activated sludge process. Elution with beef extract (Method 2) showed a better recovery for $\mathrm{AdV}$, which was detected in $90 \%$ of the analysed samples. The second most detected viruses were RVA and NoV (45\%) (Table III). RVA was detected at

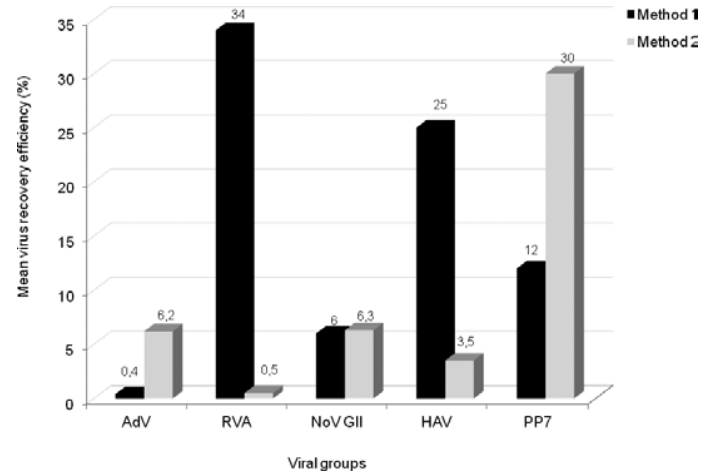

Fig. 2: recovery efficiency (\%) from each method performed in triplicate used for detecting enteric viruses. AdV: adenoviruses; HAV: hepatitis A virus; Method 1: ultracentrifugation; Method 2: beef extract; NoV GII: norovirus genogroup II; RVA: rotavirus species A.

higher concentrations by the ultracentrifugation method (Table III) and NoV GII was only detected in May, June and July, when higher concentrations of the virus were obtained by the beef extract method (Table III). HAV was only detected in two samples at relatively high concentrations (Table III). PP7 was detected in all of the spiked field samples, with lower concentrations obtained from samples collected in February and March (Table III).

Samples with negative results were submitted to a second round of experiments based on the dilution of the nucleic acids (1:10 and 1:100). The 1:10 dilution enabled detection of NoV in one sample that had been negative when tested with Method 1 (sampling date: April 11th) (Table III). This dilution also enabled detection of RVA in a sample that had been negative when tested with Method 2 (sampling date: June 27th) (Table III). However, all of the samples were still negative for HAV when this dilution was made (1:10). Negative results were obtained for all of the viruses analysed at a 1:100 dilution.

$\mathrm{pH}$ measurements showed a mean result of $6.7( \pm \mathrm{SD}$ 0.5 ) in the biosolid samples; however, samples collected in February had a lower $\mathrm{pH}$ value, at 5.5. 
TABLE III

Results of viral genome loads $\mathrm{g}^{-1}$ (dry matter) detected in anaerobically digested sludge samples using two concentration methods

\begin{tabular}{|c|c|c|c|c|c|c|c|c|c|c|}
\hline \multirow{2}{*}{$\begin{array}{l}\text { Sampling date } \\
\text { Method }\end{array}$} & \multicolumn{2}{|c|}{$\mathrm{AdV}$} & \multicolumn{2}{|c|}{ RVA } & \multicolumn{2}{|c|}{$\mathrm{NoV}$} & \multicolumn{2}{|c|}{ HAV } & \multicolumn{2}{|c|}{ PP7 } \\
\hline & 1 & 2 & 1 & 2 & 1 & 2 & 1 & 2 & 1 & 2 \\
\hline $28 \mathrm{Feb}$ & $6.8 \times 10$ & $0.9 \times 10$ & 0 & 0 & 0 & 0 & 0 & 0 & $1.0 \times 10^{3}$ & ND \\
\hline $02 \mathrm{Mar}$ & 0 & $4.2 \times 10$ & 0 & $3.8 \times 10$ & 0 & 0 & 0 & 0 & $3.8 \times 10^{3}$ & $2.6 \times 10^{3}$ \\
\hline $04 \mathrm{Mar}$ & $2.1 \times 10$ & $6.8 \times 10$ & $1.6 \times 10^{2}$ & 0 & 0 & 0 & 0 & 0 & $2.0 \times 10^{2}$ & $1.4 \times 10^{2}$ \\
\hline $14 \mathrm{Mar}$ & $1.4 \times 10$ & $1.1 \times 10^{2}$ & $7.8 \times 10$ & $6.2 \times 10$ & 0 & 0 & 0 & 0 & $3.7 \times 10^{2}$ & $1.8 \times 10^{2}$ \\
\hline $28 \mathrm{Mar}$ & 0 & $4.3 \times 10$ & 0 & 0 & 0 & 0 & 0 & 0 & $1.4 \times 10^{8}$ & $3.7 \times 10^{2}$ \\
\hline $11 \mathrm{Apr}$ & 0 & 0 & 0 & 0 & 0 & $4.8 \times 10^{2 a}$ & 0 & 0 & $1.3 \times 10^{8}$ & $4.8 \times 10^{2}$ \\
\hline $25 \mathrm{Apr}$ & $1.0 \times 10$ & $2.4 \times 10$ & 0 & 0 & 0 & 0 & 0 & 0 & $1.3 \times 10^{8}$ & $9.4 \times 10^{7}$ \\
\hline 16 May & 0 & $2.7 \times 10^{2}$ & 0 & 0 & $6.4 \times 10$ & $1.2 \times 10^{2}$ & 0 & 0 & $1.3 \times 10^{8}$ & $5.4 \times 10^{7}$ \\
\hline 13 Jun & 0 & $1.9 \times 10^{2}$ & 0 & 0 & $1.4 \times 10$ & $1.5 \times 10^{2}$ & 0 & $2.0 \times 10^{4}$ & $3.1 \times 10^{7}$ & $5.6 \times 10^{7}$ \\
\hline 27 Jun & $2.4 \times 10^{3}$ & $3.6 \times 10^{2}$ & $2.5 \times 10^{a}$ & 0 & $2.2 \times 10$ & $2.3 \times 10^{2}$ & $4.8 \times 10^{3}$ & 0 & ND & $9.2 \times 10^{7}$ \\
\hline $11 \mathrm{Jul}$ & 0 & $1.6 \times 10^{2}$ & 0 & $7.2 \times 10$ & $1.8 \times 10$ & $5.2 \times 10^{2}$ & 0 & 0 & $1.0 \times 10^{8}$ & ND \\
\hline Positive/total (n) & $5 / 11$ & $10 / 11$ & $3 / 11$ & $3 / 11$ & $4 / 11$ & $5 / 11$ & $1 / 11$ & $1 / 11$ & $10 / 10$ & $9 / 9$ \\
\hline
\end{tabular}

a: diluted nucleic acids (1:10); AdV: adenoviruses; HAV: hepatitis A virus; Method 1: ultracentrifugation; Method 2: beef extract; ND: not done; NoV GII: norovirus genogroup II; RVA: rotavirus species.

\section{DISCUSSION}

Viruses are charged particles that can be highly concentrated in biosolids due to aggregation and adhesion to sludge solids (Sidhu \& Toze 2009). Several methods have been tested for detecting viruses in sewage sludge samples (Monpoeho et al. 2004, Belguith et al. 2006, Guzmán et al. 2007); however, few comparisons between the different viruses have been made regarding recovery yields of the different viral groups, specifically HAV and other enteric viruses (Sidhu \& Toze 2009). In some cases, the negative results can be attributed to the inefficiency of the methods used.

The methods chosen for this study have been recommended by the Resolution of the National Council of the Environment (CONAMA 2006), which provides guidelines for monitoring enteric viruses in biosolids. These guidelines recommend protocols that use beef extract or those based on ultracentrifugation for virus concentration. PCR is also recommended for the detection of some viral groups, including RV and HAV (CONAMA 2006).

The primers and probes used in TaqMan qPCR assays target more conservative regions of the virus genome and have been considered suitable for detecting enteric viruses in several environmental matrices (Villar et al. 2006, Fumian et al. 2010, 2011, Prado et al. 2011a, Simmons \& Xagoraraki 2011). However, there is some difficulty in amplifying targeted nucleic acids in biosolid samples due to the presence of a variety of inhibitors, such as humic and fulvic acids, fats, proteins, organic and inorganic compounds, including polyphenols and heavy metals that form complexes with nucleic acids and inhibit amplification enzymes (Sano et al. 2003, Sidhu \& Toze 2009, Rock et al. 2010).
The results obtained in this study indicate that different virus recovery rates are the result of the different virus concentration methods used. The mean recovery rates of the beef extract method were $6.2 \%$ and $6.3 \%$ for $\mathrm{AdV}$ and $\mathrm{NoV}$, respectively, and are similar to the results obtained by Sano et al. (2003), who detected a $7 \%$ recovery rate for poliovirus from sewage sludge by RT-PCR.

Ultracentrifugation was considered the best alternative method for detecting RVA and HAV in the spiked experiments, but not suitable for naturally contaminated biosolid samples. It is possible that in the spiked experiments, the original organic matter was compromised due to autoclaving, contributing to an elevated recovery efficiency rate for the concentration methods.

However, the mean recovery rate of AdV was very low when using glycine buffer followed by ultracentrifugation. Rock et al. (2010) has reported that beef extract and glycine buffer can concentrate different inhibitor compounds responsible for causing different results when using a qPCR assay. Nevertheless, it is difficult to determine which compound affected the qPCR efficiency because ultracentrifugation was used as the final step to concentrate the viruses. The pellet that is generated may contain viruses and other substances, such as suspended solids of the final eluate.

AdV had a higher level of adsorption in this particulate matter because the virus size affects the interaction mechanisms with the colloidal particles of the environmental matrices (Dowd et al. 1998). Moreover, the presence of suspended solids in the final eluate can affect the results of the nucleic acid extraction. A higher volume of glycine may be more suitable for detecting viruses by ultracentrifugation. 
Several strategies can be adopted to minimise or predict the interference of environmental inhibitors in PCR reactions (Viau \& Peccia 2009, Rock et al. 2010), but the dilution of nucleic acids appears to be the simplest of these strategies, specifically by avoiding the addition of other reagents. Nevertheless, in contrast to the results obtained from the spiked experiments, nucleic acids from the field samples diluted at 1:100 showed negative results, which indicates that the VL of these samples may have been diluted below the detectable limits of the assays.

The use of an IC (PP7 Bacteriophage) to monitor the stages of detection provides an interesting solution for avoiding false negative results. When high concentrations of PP7 were seeded in the field samples, the VLs recovered were low in some samples. The negative results obtained for some of the enteric viruses in these samples may be attributed to variable compositions of the biosolids.

Experiments using anaerobically digested sludge samples detected at least one virus in each of the analysed samples. Comparatively, AdV was the most detected virus, demonstrating its widespread dissemination in treated sewage sludge. These results support the hypothesis that AdV could be a good indicator for evaluating the presence of enteric viruses in sewage sludge samples (Bofill-Mas et al. 2006, Schlindwein et al. 2010, Wong et al. 2010). While Bofill-Mas et al. (2006) reported similar concentrations for $\mathrm{AdV}$, other investigations have found higher AdV genome loads in sewage sludge treated by $\mathrm{MAD}$, with concentrations varying from $10^{4}-10^{6} \mathrm{GC} \mathrm{g}^{-1}$ (d.m.) (Viau \& Peccia 2009, Wong et al. 2010).

RVA can be detected at higher levels $(\geq 45 \%)$ in biosolid samples; recent studies have shown a large dissemination of RVA $(\geq 90 \%)$ in wastewaters from RJ (Fumian et al. 2011, Prado et al. 2011a). However, researchers hypothesise that RV is poorly adsorbed in solid fractions of sludge (Arraj et al. 2005, Sidhu \& Toze 2009), possibly explaining the lower frequency of detection and VLs when compared with the amount of $\mathrm{AdV}$ found in these samples.

Interestingly, NoV GII was predominantly detected in the colder months, suggesting a higher burden and circulation of these viruses during this period and corroborating previous results concerning the peak occurrences of NoV in Brazilian sewage samples (Victoria et al. 2010).

HAV was poorly recovered from the sewage sludge samples, corroborating data from other studies (Schlindwein et al. 2010, Wong et al. 2010, Simmons \& Xagoraraki 2011). The lower frequency of HAV detection in biosolids can be expected because improvements in sanitary and socioeconomic conditions may be preventing the circulation of these viruses in the community and consequently, in wastewaters, as recently verified in studies conducted in RJ (Prado et al. 2011b). However, another explanation is related to the low detection limits of the methods used to detect HAV in biosolids, as demonstrated in this study and by other authors (Jebri et al. 2012). Therefore, the detection of HAV in biosolids can be underestimated, primarily when low VLs are circulating in these environments.
Although viral infectivity is not determined by methods based on nucleic acid amplification, studies have confirmed that a great proportion of viral genomes detected by molecular methods correspond with viable infectious particles detected in sewage sludge or biosolids (Schlindwein et al. 2010, Wong et al. 2010, Simmons \& Xagoraraki 2011). Moreover, the aggregation of viruses onto sludge flocs could prevent viral inactivation (Sidhu \& Toze 2009).

The concentration method using beef extract elution followed by qPCR assay seems suitable for detecting $\mathrm{AdV}$ in biosolids. However, other concentration methods should be investigated for the detection of other viruses, especially HAV, to avoid inaccuracies related to potential contamination and quantification of viruses in biosolids, ensuring a reliable public health risk analysis.

\section{ACKNOWLEDGEMENTS}

To Dr Marise Dutra Asensi and Dr Liliane Myiuki (Laboratory of Bacteriology, IOC/Fiocruz), for supporting bacteriophage PP7 replication, and to the WWTP staff, for supplying the sewage sludge samples under the agreement between Fiocruz and CEDAE.

\section{REFERENCES}

Arraj A, Bohatier J, Laveran H, Traore O 2005. Comparison of bacteriophage and enteric virus removal in pilot scale activated sludge plants. J Appl Microbiol 98: 516-524.

Belguith K, Hassen A, Aouni M 2006. Comparative study of four extraction methods for enterovirus recovery from wastewater and sewage sludge. Bioresour Technol 97: 414-419.

Bofill-Mas S, Albinana-Gimenez N, Clemente-Casares P, Hundesa A, Rodriguez-Manzano J, Allard A, Calvo M, Girones R 2006. Quantification and stability of human adenoviruses and polyomavirus JCPyV in wastewater matrices. Appl Environ Microbiol 72: 7894-7896.

CONAMA - Conselho Nacional do Meio Ambiente 2006. Guidelines and procedures for use of sewage sludge in agriculture soil. Available from: mma.gov.br/port/conama/res/res06/res37506.pdf.

Dowd SE, Pillai SD, Wang S, Corapcioglu MY 1998. Delineating the specific influence of virus isoelectric point and size on virus adsorption and transport through sandy soils. Appl Environ Microbiol 62: 405-410.

Fumian TM, Leite JPG, Castello AA, Gaggero A, Caillou MSL, Miagostovich MP 2010. Detection of rotavirus A in sewage samples using multiplex qPCR and an evaluation of the ultracentrifugation and adsorption-elution methods for virus concentration. J Virol Methods 170: 42-46.

Fumian TM, Leite JPG, Rose TL, Prado T, Miagostovich MP 2011. One year environmental surveillance of rotavirus specie A (RVA) genotypes in circulation after the introduction of the Rotarix vaccine in Rio de Janeiro, Brazil. Water Res 45: 5755-5763.

Girones R, Ferrús MA, Alonso JL, Rodriguez-Manzano J, Calgua B, Corrêa AB, Hundesa A, Carratala A, Bofill-Mas S 2010. Molecular detection of pathogens in water - The pros and cons of molecular techniques. Water Res 44: 4325-4339.

Godfree A, Farrell J 2005. Processes for managing pathogens. J Environ Qual 34: 105-113.

Guzmán C, Jofre J, Blanch AR, Lucena F 2007. Development of a feasible method to extract somatic coliphages from sludge, soil and treated biowaste. J Virol Methods 144: 41-48. 
Heim A, Ebnet C, Harste G, Pring-Akerblom P 2003. Rapid and quantitative detection of human adenovirus DNA by real-time PCR. J Med Virol 70: 228-239.

IBGE - Instituto Brasileiro de Geografia e Estatística 2008. Pesquisa Nacional de Saneamento Básico. Available from: ibge.gov.br/home/ estatistica/populacao/condicaodevida/pnsb2008/default.shtm.

Jebri S, Jofre J, Barkallah I, Saidi M, Hmaied F 2012. Presence and fate of coliphages and enteric viruses in three wastewater treatment plants effluents and activated sludge from Tunisia. Environ Sci Pollut Res Int 19: 2195-2201.

Kageyama T, Kojima S, Shinohara M, Uchida K, Fukushi F, Hoshino FB, Takeda N, Katayama K 2003. Broadly reactive and highly sensitive assay for Norwalk-like viruses based on real-time quantitative reverse transcription-PCR. J Clin Microbiol 41: 1548-1557.

Monpoeho S, Maul A, Bonnin C, Patria L, Ranarijaona S, Billaudel S, Ferré V 2004. Clearance of human-pathogenic viruses from sludge: study of four stabilization processes by real-time reverse transcription-PCR and cell culture. Appl Environ Microbiol 70: 5434-5440.

Pina S, Jofre J, Emerson SU, Purcell RH, Girones R 1998. Characterization of a strain of infectious hepatitis $\mathrm{E}$ virus isolated from sewage in an area where hepatitis $\mathrm{E}$ is not endemic. Appl Environ Microbiol 64: 4485-4488

Prado T, Silva DM, Guilayn WC, Rose TL, Gaspar AMC, Miagostovich MP 2011a. Quantification and molecular characterization of enteric viruses detected in effluents from two hospital wastewater treatment plants. Water Res 45: 1287-1297.

Prado T, Fumian TM, Miagostovich MP, Gaspar AMC 2011b. Monitoring the hepatitis A virus in urban wastewater from Rio de Janeiro, Brazil. Trans R Soc Trop Med Hyg 106: 104-109.

Rajal VB, McSwain BS, Thompson DE, Leutenegger CM, Kildare BJ, Wuertz S 2007. Validation of hollow fiber ultrafiltration and realtime PCR using bacteriophage PP7 as surrogate for the quantification of viruses from water samples. Water Res 41: 1411-1422.
Rock C, Alum A, Abbaszadegan M 2010. PCR inhibitor levels in concentrates of biosolid samples predicted by a new method based on excitation-emission matrix spectroscopy. Appl Environ Microbiol 76: 8102-8109.

Sano D, Fukushi K, Yoshida Y, Omura T 2003. Detection of enteric viruses in municipal sewage sludge by a combination of the enzymatic virus elution method and RT-PCR. Water Res 37: 3490-3498.

Schlindwein AD, Rigotto C, Simões CMO, Barardi CRM 2010. Detection of enteric viruses in sewage sludge and treated wastewater effluent. Water Sci Technol 61: 537-544.

Sidhu JPS, Toze SG 2009. Human pathogens and their indicators in biosolids: a literature review. Environ Int 35: 187-201.

Simmons FJ, Xagoraraki I 2011. Release of infectious human enteric viruses by full-scale wastewater utilities. Water Res 45: 3590-3598.

US EPA - Environmental Protection Agency of the United States 2003. Control of pathogens and vector attraction in sewage sludge. Under 40 CFR Part 503, Appendix H - Method for the recovery and assay of total culturable viruses from sludge. (EPA/625/R-92/013). Available from: epa.gov/nrmrl/pubs/625r92013/625R92013.pdf.

Viau E, Peccia J 2009. Survey of wastewater indicators and human pathogen genomes in biosolids produced by class A and class B stabilization treatments. Appl Environ Microbiol 75: 164-174.

Victoria M, Guimarães FR, Fumian TM, Ferreira FFM, Vieira CB, Shubo T, Leite JPG, Miagostovich MP 2010. One year monitoring of norovirus in a sewage treatment plant in Rio de Janeiro, Brazil. J Water Health 8: 158-165.

Villar LM, de Paula VS, Diniz-Mendes L, Lampe E, Gaspar AMC 2006. Evaluation of methods used to concentrate and detect hepatitis A virus in water samples. J Virol Methods 137: 169-176.

Wong K, Onan BM, Xagoraraki I 2010. Quantification of enteric viruses, pathogen indicators and Salmonella bacteria in class B anaerobically digested biosolids by culture and molecular methods. Appl Environ Microbiol 76: 6441-6448. 